\title{
The Use of Evolutionary Algorithms for Optimization in the Modern Entrepreneurial Economy: Interdisciplinary Perspective
}

\author{
Marek Sieja, Krzysztof Wach
}

\begin{abstract}
A B S T R A C T
Objective: The objective of the article is to present the concept of evolutionary algorithms and indicates the possibility of their implementation for the needs of the economy, especially the entrepreneurial economy.

Research Design \& Methods: This conceptual article relies on literature review and desk research. The article elaborates on available literature via a systematic literature review methodology.

Findings: The article elaborates on the idea of action and typology of evolutionary algorithms as the broadly applied search and optimisation technique based on Darwin's theory of evolution and modern natural genetics. The article focuses on the examples of evolutionary algorithms application in economics and management.

Implications \& Recommendations: The current state of applications of evolutionary algorithms for the needs of the economy and business confirms that we still await an implementation breakthrough. The growing interest in evolutionary algorithms in connection with the dynamic development of information technologies may lead to the use of evolutionary algorithms in hybrid systems, which in turn will contribute to significant progress in optimization theory.
\end{abstract}

Contribution \& Value Added: The article structures scientific knowledge on the application of evolutionary algorithms in business and economy. The promotion of the application of evolutionary algorithms in economics, finance, and management is mainly limited to journals in operational research, decision-making process, or financial engineering, whereas this article includes entrepreneurship.

\begin{tabular}{lll}
\hline Article type: & $\begin{array}{l}\text { conceptual article } \\
\text { evolutionary algorithms; genetic algorithms; computational tech- } \\
\text { Keywords: }\end{array}$ & $\begin{array}{ll}\text { niques; optimization techniques; entrepreneurial economy } \\
\text { C63, C65 }\end{array}$ \\
JEL codes: & Revised: 30 September $2019 \quad$ Accepted: 1 December 2019
\end{tabular}

\section{Suggested citation:}

Sieja, M., \& Wach, K. (2019). The Use of Evolutionary Algorithms for Optimization in the Modern Entrepreneurial Economy: Interdisciplinary Perspective. Entrepreneurial Business and Economics Review, 7(4), 117-130. https://doi.org/10.15678/EBER.2019.070407 


\section{INTRODUCTION}

Knowledge-based economy or entrepreneurial economy (Wach, 2015), especially various drivers of entrepreneurial activities in the entrepreneurial society (Zygmunt, 2018; Rogalska, 2018; Zajkowski \& Domańska, 2019), and the intensive and turbulent development of information technologies (Köppelová \& Jindrová, 2017; 2019) increased the popularity of the application of the latest achievements in the field of artificial intelligence (Wiśniewska, Lula, Oczkowska, \& Wójcik, 2019). Current scholarship shows high interdisciplinarity and convergence of individual scientific disciplines. For example, earth and life sciences utilise game theory developed within economics, technical sciences seek inspiration in the theory of evolution developed by biologists, and economics draw on the theory of chaos elaborated by physicists. Knowledge receives support from artificial intelligence, whose application accelerates the progress of research (Kožíšek \& Vrana, 2017) and the modern business practice (Khan et al., 2017), and what is more, such aplications can be named distruptive innovations (Benazzouz, 2019). A good example of the practical use of artificial intelligence are evolutionary algorithms. These are widely used in many fields of science, primarily in pragmatic engineering and construction issues, or managerial and investment decisions, but also in marketing (Hurley, Moutinho, \& Stephens, 1995). Evolutionary algorithms (EG) gain popular in matters of optimization in the field of economic sciences: economics, finance, management (Deb, Pratap, Agarwal, \& Meyarivan, 2002). EG are used in operational research and financial engineering, in which quantitative methods are key (Mukerjee, Biswas, Deb, \& Marhur, 2002). EG gain importance in view of the development of Big Data (Batistic \& van der Laken, 2019) and Industry 4.0, including the development of blockchain technology (Wyciślak, 2017; Nowiński \& Kozma, 2017; Ilyash, Dzhadan, \& Ostasz, 2018; Prokop \& Karbowski, 2018).

The current article presents the idea of evolutionary algorithms and indicates how can we implement them in the economy, especially the present knowledge-based economy. The article poses the following exploratory research questions:

RQ1: How do evolutionary algorithms work from a computational - mathematical and engineering - standpoint?

RQ2: What are the pros and cons of using evolutionary algorithms to optimize economics, finance, and management?

RQ3: What are the current and potential fields of application of evolutionary algorithms in economics, finance, management, along with - especially - entrepreneurship and international business?

This conceptual article relies on literature review and desk research. The article elaborates on available literature via a systematic literature review methodology. The article consists of three parts. The first will describe the research methodology, including the principles of selection of reference sources. The second, main part will undertake a conceptual review of the literature and proposes answers to the three research questions above. The third, final part will summarise the article and outline further research directions. 


\section{MATERIAL AND METHODS}

The article elaborates on available literature and online sources. We searched through secondary literature with a combination of two screening terms "evolutionary algorithms" and one of the possible uses described in the article: "finance," "economics," "management," "marketing," or "business." This article uses a qualitative design of research based on cause-effect analysis, along with predictive synthesis, modelling, induction, and description of the synthetic and systematic literature review (Figure 1).

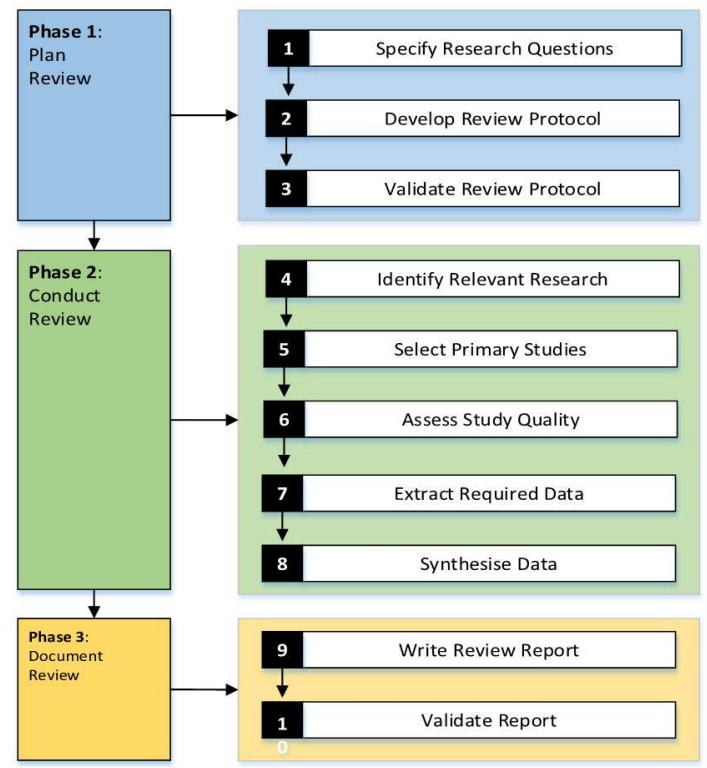

Figure 1. Methodology of the systematic literature review

Source: Brereton, Kitchenham, Budgen, Turner, \& Khalil (2007).

Smooth and efficient conducting of scientific research requires a procedure according to pre-determined steps in order to obtain the most valuable cognitive effects of the research process (Babbie, 2012). The nature of the research project is multidimensional, it realises exploratory, descriptive, analytical, and predictive purposes (Collis \& Hussey, 2009). The thorough literature study was prepared in order to conceptualise and operationalise the research problem. Therefore, the main research method was literature review and its constructive critics, a critical literature review proposed by Fisher (2010).

\section{LITERATURE REVIEW AND CONCEPTUALIZATION}

\section{The Operational Principle of Evolutionary Algorithms (RQ1)}

EAs are a type of heuristic methods based on Darwinian theory of evolution (Lichy, Mazur, Stolarek, \& Lipiński, 2018). Thus, we may define EAs as a transposition of the Darwinian metaphor into a stochastic search and optimization algorithm that uses advanced mathematical operations. 
To understand how EAs work, it is best to refer directly to Charles Darwin's theory of evolution. The mechanism and course of biological evolution is based on the following five assumptions (Hurley, Moutinho, \& Stephens, 1995; Sieja \& Wach, 2008):

- limited resources: individuals must compete for the same environmental resources,

- fitness: some features are more desirable in the competition for environmental resources, hence specific features give individuals the competitive advantage in a certain environment,

- heredity: individuals inherit the features of their ancestors,

- variation: the heredity process is not accurate but fraught with changes that can take the form of mutations (primary variation) and recombination i.e. crossover (secondary variation), caused by natural selection, genetic drift, or the level of gene flow,

- natural selection (survival of the fittest): more adapted individuals to an environment have a better chance of surviving and producing offspring than the less adapted individuals.

To elaborate on Darwin's theory of evolution, let us add that a specimen means a genotype with an appropriate genetic code and features identical with genes; i.e. the genotype consists of chromosomes and the chromosome consists of genes. Particular individuals have a certain characteristic set: a phenotype. According to the theory of evolution, if only the fittest specimen survive then particular specimen strive to fit the best, which is possible by acquiring the best features. Therefore, specimen seek the best features in other specimen, so that - in the case of inheritance - the new specimen would fit better to the environment. Through heredity, there occur mechanisms called genetic operations (Sieja \& Wach, 2008):

- mutation, i.e. random variation that leads to the emergence of new genotypes due to perturbation one of the parent specimen,

- crossover, i.e. a recombination of existing genes, which is the reason for the persistence of genetic diversity,

- inversion, which changes a fragment of the chromosome.

These operations appear along with various phenomena, e.g. natural selection, which favours or eliminates certain genotypes; isolation, which hinders the crossover of specimen; genetic drift, or oscillation in gene frequency in small, isolated populations; a sharp change in environmental conditions.

EAs borrow the vocabulary of natural genetics, so the above synthesis of natural phenomena allows us to present the idea of EAs. The concept of evolutionary problem-solving stems from the regularity that a population of individuals (instead of specimens) is subject to subsequent evolutionary steps, as they are also candidates for solving a task. Each individual represents a potential solution to the problem. Each one may receive a numerical value that determines its fit to the environment, i.e. the quality of the individual's solution. The evolutionary process corresponds to the search for a space of potential solutions which, on the one hand, employs the best solutions so far and, on the other hand, broadly explores the searched space (Shvedovsky, Standrik, \& Bilan, 2016).

The operation of the EA boils down to an operation loop (Figure 1) that includes reproduction (preselection), genetic operations (crossover, mutation), evaluation, and succession (postselection; Arabas 2004; Goldberg 1989). 


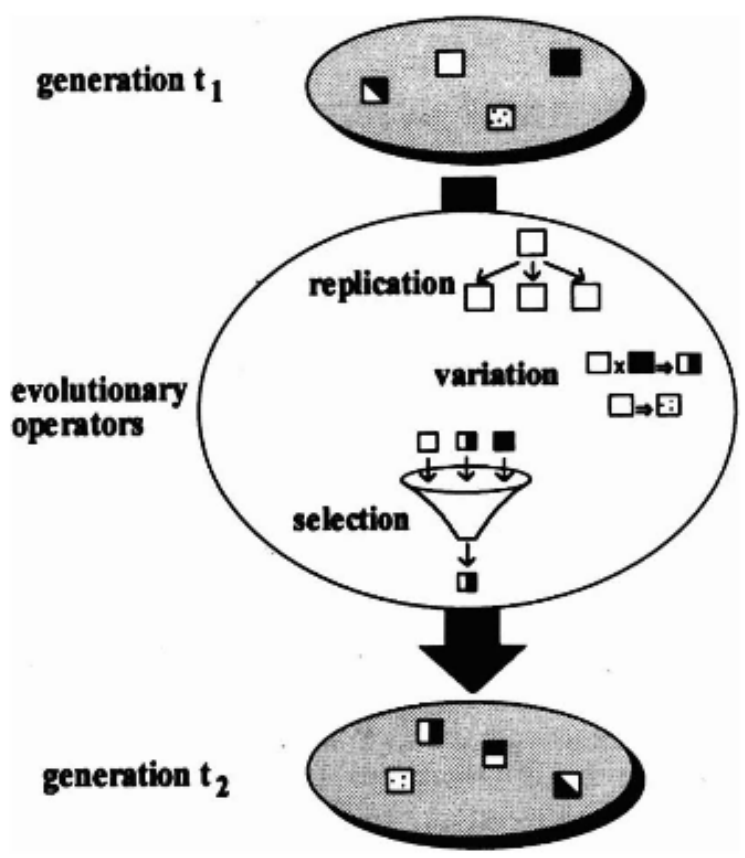

Figure 2. Operational cycle of a basic evolutionary algorithm Source: Biethahn and Nissen (1994, p. 184).

We randomly select individuals from the base population during reproduction, with the randomness of selection for reproduction accounting for the fitness value of these individuals, which means that better fitting individuals are more likely to reproduce. Some individuals may reproduce many times, while other will not be selected for duplication even once. In this way, a new (temporary) population emerges from the selection of better fitting individuals (Michalewicz \& Fogel, 2003).

We then subject copies created as a result of reproduction to genetic operations: crossover and mutation. Some transform under differentiating operators, which creates new solutions. Individuals created as a result of genetic operators constitute the descendant population. Crossover consists of randomly matching strings from the base population in pairs and then crossover them, i.e. swapping places in both elements of the pair, thus creating two new strings that are part of a new generation. In turn, mutation consists of sporadic, accidental change in the value of the code string element.

Next, the descendant population undergoes the assessment of the environment: the fitness indicator plays the target role in this case. Thus, the fitness function is a measurement of profit, utility, or other quantity that we want to maximize (Goldberg, 1989). As a result, there occurs succession, i.e. a new base population emerges that may contain individuals from both the descendant population and the old base population.

Scholars know two varieties of selection: reproduction and succession. The former assumes that the new base population emerges exclusively from the descendant population. The latter chooses from both the descendant population and the best individuals from the 
base population. Reproduction can be conducted in many ways: proportional (roulette) reproduction, modified proportional reproduction, tournament reproduction, threshold reproduction. The same applies to succession: elitist succession, succession with complete replacement, succession with partial replacement (Arabas, 2004, pp. 114-134).

The above operations create evolution loops, in which the EA is executed cyclically (in a loop) until the algorithm stop criterion occurs (stop conditions). The algorithm may stop in two situations:

- the adaptation of individuals is large enough, i.e. a certain number of solutions are generated,

- the state of the base population indicates a stagnation of the algorithm, i.e. a certain period of time is exceeded.

There are many types of EAs. However, it is difficult to talk about their classification - only cite some typologies. Currently, we distinguish (Michalewicz \& Fogel, 2003; Arabas, 2011):

- genetic algorithms,

- genetic programming,

- evolution strategies,

- evolutionary programming,

- classifier systems,

- differential evolution,

- memetic algorithms.

A recent use and compilation of various multi-objective evolutionary algorithms especially genetic algorithms - appears in Deb (2001) and Coello (1999).

Genetic algorithms (GAs) are search and optimization algorithms inspired by the principles of natural evolution. According to the specifics of genetic algorithms, searching for the optimal value occurs in three steps (Arabas 2011; Goldberg 1989; Michalewicz, 1996): (1) reproduction, (2) crossing, (3) mutation.

In the first stage of work of GA an initial population, comprised of an even number of chromosomes, is selected (Table 1). Each chromosome comprises of detectors. The number of detectors represents the number of switchings in case of a signal with one constraint, or the number of peaks $T$ of the triangular signal.

Table 1. Population of chromosomes and adaptation coefficient for each chromosome

\begin{tabular}{|c|c|c|c|c|c|c|}
\hline \multirow{2}{*}{$\begin{array}{c}\text { Chromo- } \\
\text { some }\end{array}$} & \multicolumn{5}{|c|}{ Detectors } & \multirow{2}{*}{$\begin{array}{c}\text { Adaptation } \\
\text { coefficient }\end{array}$} \\
\cline { 2 - 7 } & $\mathbf{1}$ & $\mathbf{2}$ & $\mathbf{3}$ & $\ldots$ & $\boldsymbol{r}$ & $\tilde{I}_{1}$ \\
\hline 1 & $n_{11}$ & $n_{12}$ & $n_{13}$ & $\ldots$ & $n_{1 r}$ & $\tilde{I}_{2}$ \\
\hline 2 & $n_{21}$ & $n_{22}$ & $n_{23}$ & $\ldots$ & $n_{3 r}$ & $\tilde{I}_{3}$ \\
\hline 3 & $n_{31}$ & $n_{32}$ & $n_{33}$ & $\ldots$ & $\ldots$ & $\ldots$ \\
\hline$\ldots$ & $\ldots$ & $\ldots$ & $\ldots$ & $\ldots$ & $n_{m r}$ & $\tilde{I}_{m}$ \\
\hline
\end{tabular}

Source: Tomczyk (2006, p. 97) and Sieja (2010 p. 84).

The value of index (2) is determined for every chromosome and then the so-called adaptation coefficient - the percentage participation of each chromosome in the value 
of summarised criterion - is calculated on the basis of the obtained results and on the basis of the relation (1):

$$
\begin{gathered}
\tilde{I}_{s}=\tilde{I}_{1}+\tilde{I}_{2}+\tilde{I}_{3}+\ldots+\tilde{I}_{m} \\
\tilde{I}_{1}{ }^{\prime}=\tilde{I}_{1} / \tilde{I}_{s} \cdot 100[\%] \\
\cdots \\
\tilde{I}_{m}{ }^{\prime}=\tilde{I}_{m} / \tilde{I}_{s} \cdot 100[\%]
\end{gathered}
$$

where:

$\tilde{I}_{s}$ - is the value of summarised criterion;

$\tilde{I}_{1}^{\prime}, \tilde{I}_{2}^{\prime}, \ldots, \tilde{I}_{m}^{\prime}$ - represent the percentage participation of the particular adaptation coefficients in the summarised criterion.

The determination of adaptation coefficients for each of the chromosomes leads to estimating their usefulness in the particular population. In case, when the differences between obtained values of the adaptation coefficients are small, it is necessary to conduct a scaling operation of the adaptation coefficient, as the following steps of the work of the genetic algorithm might not give the desired results. In this work, we apply the very popular linear scaling.

In the next step, the reproduction operation was executed, in which - according to the probability calculated from (1) - the chromosomes are selected from the initial population set. Depending on the value of the adaptation coefficient, a particular chromosome has smaller or greater chances of selection to the next generation. There are several methods of calculating those "chances" for particular chromosomes. The most popular method is the roulette wheel method, which means that the sampling process is conducted the number of times equal to the number of chromosomes in the population while the sampling results are transferred to the new, descendant population. All chromosomes are characterised by a different probability of selection, proportional to the value of the adaptation coefficient. Thus, the reproduction procedure creates a new population of chromosomes.

The next stage is crossing. From the fact that detectors assume the form of real positive numbers, one may derive that if one pair of chromosomes takes part in the crossing process then all pairs of detectors are crossed. The chromosomes are paired coincidentally. The number from the $[0,1]$ interval is sampled for the assumed crossing probability $P_{c}$. If the sampled number is from the $\left[0, P_{c}\right]$ interval, then the crossing process occurs. Otherwise, the corresponding detectors of the associated chromosomes are not crossed. The crossing $P_{c}$ is usually set at a high level, around 0.9.

The crossing process is conducted in accordance to the following formula (Tomczyk, 2006; Layer \& Tomczyk, 2010):

where:

$$
\begin{gathered}
n_{11}^{\prime}=(1-\alpha) n_{11}+n_{21} \\
n_{21}^{\prime}=\alpha n_{11}+(1-\alpha) n_{21}
\end{gathered}
$$

$n_{11}^{\prime}$ - is a detector of the first descendant chromosome;

$n_{21}^{\prime}$ - is a detector of the second descendant chromosome. 
The $\alpha$ coefficient has to be selected in such a way, that the crossing process does not cause descendant detectors on $i$-th position to assume values greater than the detectors in position $(i+1)$ and lower than detectors in position $(i-1)$.

The last stage of the GA operation is the process of mutation. In the case of every detector that are part of the descendant chromosomes, we ask whether the mutation process or will not happen. This process is usually conducted with a very low probability; usually at the level of 0.01 .

Often encountered variation of the mutation process is linear mutation, conducted with the use of the following formula (Tomczyk, 2006; Layer \& Tomczyk, 2010):

$$
\begin{gathered}
n_{1 r}^{\prime \prime}=\left(n_{1 r+1}-n_{1 r-1}\right) \alpha+n_{1 r-1}^{\prime} \\
\alpha \in<0,1>, r=1,2, \ldots, m
\end{gathered}
$$

after completing the mutation process, the genetic algorithm process repeats. The number of populations of the algorithm that realises the search in the space of $x(n)$ signals will be as large as possible. However, one should consider that - for a larger population the time of work of the algorithm extends significantly.

\section{The Pros and Cons of Using Evolutionary Algorithms (RQ2)}

The practical implementation of EAs dates back to the 1950s, while most assume that the use of the evolutionary process model in computational methods begins with the 1975 work of John Holland, Adaptation in Natural and Artificial Systems (Holland, 1975). Currently, evolutionary algorithms experience their heyday, which can be demonstrated by the rapid increase in publications in this field.

Jones, Mirrazavi and Tamiz (2002) indicate that the research progress in the implementation of EAs is significant yet partial, because the progress of information technologies we currently face contributes to the development of increasingly advanced solutions based on EAs.

EAs differ from traditional optimization methods due to the following features (Biethanh \& Nissan, 1994, p. 185; Goldberg, 1989, p. 23):

- they operate on a vector that represents decision variables (task parameters) as code strings (they do not directly process task parameters, but their encoded form),

- they search the entire space, simultaneously seeking solutions from many vantage points (they conduct searches from a population of individual points),

- they do not require detailed knowledge about the nature of the problem but only information about the quality of solutions (their match; though such knowledge may contribute to faster implementation), because they only use the objective function, not its derivatives or other auxiliary information,

- they intentionally use stochastic processes to narrow down intelligent search space research to the most promising regions of search space (they use probabilistic rather than deterministic selection methods).

The use of EAs as an optimisation technique has many advantages (Table 2). EAs are even referred to as last resort methods (Arabas, 2004, p. 20). 
Table 2. Main advantages and disadvantages of EA as an optimisation method

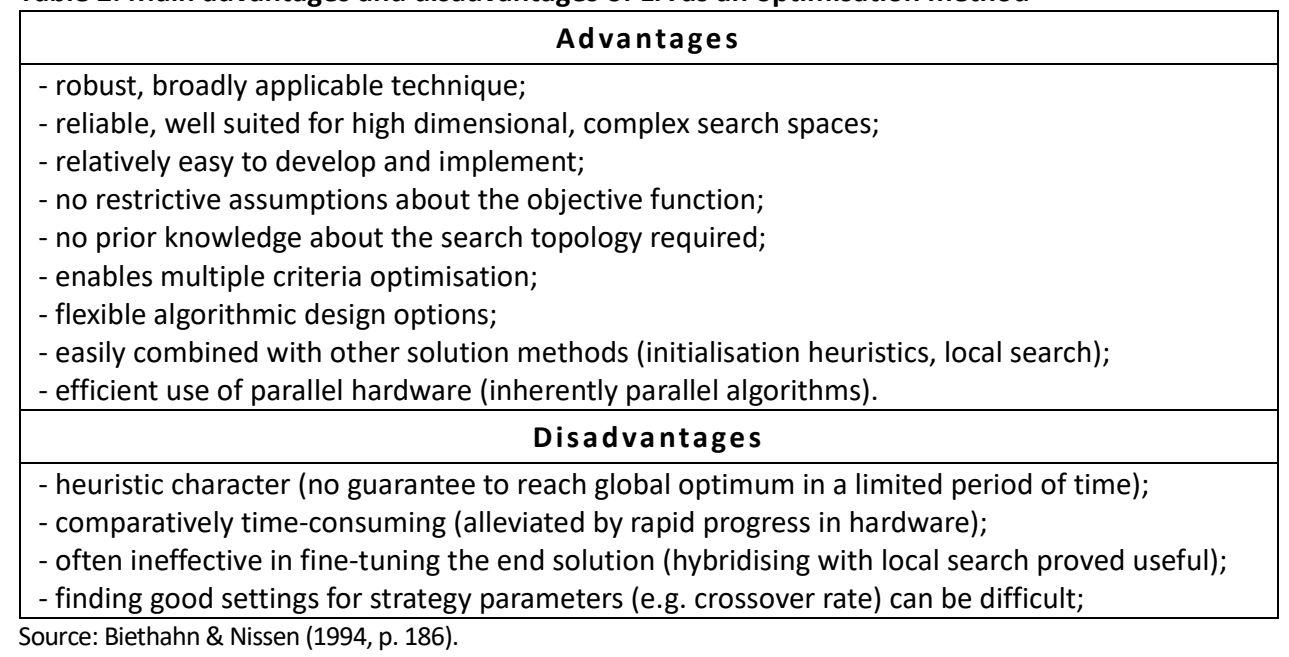

\section{The Application of Evolutionary Algorithms in Economics and Business (RQ3)}

In times of knowledge-based economy, knowledge is of key importance, even if it is interpreted broadly. The application of the achievements of modern information technology currently allows the use of previously unavailable optimization techniques. Economic decisions - especially decisions of stock market players, insurers, or even managers - are made in conditions of uncertainty or risk, hence their optimization is one of the most important issues for decision-makers. The possibilities offered by EAs increased the interest in their application for the needs of economic sciences, mainly in pragmatic management and investment decision-making. Currently, we can indicate many typical possibilities of the application of EAs in economic sciences: in economics, finance, management, commodity science, and production engineering (Table 3 ).

Table 3. The application of evolutionary algorithms in the knowledge-based economy

\begin{tabular}{|l|l|l|}
\hline Field of Use & \multicolumn{1}{|c|}{ Examples of use } & \multicolumn{1}{|c|}{ Reference } \\
\hline Economy & $\begin{array}{l}\text { - Development of the world economic } \\
\text { model; } \\
\text { - Resource allocation. }\end{array}$ & Johnstone (1993); \\
\hline $\begin{array}{l}\text { Finance and } \\
\text { financial } \\
\text { services }\end{array}$ & - Risk management; & - Insurance risk estimation; \\
& - Credit scoring; & Noble (1990); \\
& - Determining creditworthiness; & Margarita (1991, 1992); \\
& - Bankruptcy forecasting; & Burke (1993); \\
& - Late payment anticipation; & Johnstone (1993); \\
& - Time cycle analysis; & Nottola et al. (1992). \\
& - Financial fraud detection; & \\
& - Expenditures allocation for various social \\
& programs. & \\
\hline
\end{tabular}




\begin{tabular}{|c|c|c|}
\hline Field of Use & Examples of use & Reference \\
\hline $\begin{array}{l}\text { Capital } \\
\text { markets }\end{array}$ & $\begin{array}{l}\text { - Trading strategy search; } \\
\text { - Stock trading; } \\
\text { - Speculative stock markets; } \\
\text { - Stock market simulation; } \\
\text { - Portfolio optimisation; } \\
\text { - Shares portfolio optimisation; } \\
\text { - Stock market player model; } \\
\text { - Financial markets modelling. }\end{array}$ & $\begin{array}{l}\text { Noble (1990); } \\
\text { Margarita (1991, 1992); } \\
\text { Burke (1993); } \\
\text { Johnstone (1993); } \\
\text { Nottola et al. (1992). }\end{array}$ \\
\hline $\begin{array}{l}\text { Logistics } \\
\text { and } \\
\text { transportati } \\
\text { on }\end{array}$ & $\begin{array}{l}\text { - Freight train routes preparation; } \\
\text { - Wheeled vehicle routes preparation; } \\
\text { - Aircraft landing order; } \\
\text { - Monorail trains order. }\end{array}$ & $\begin{array}{l}\text { Baker and Schaffer (1991); } \\
\text { Thangiah et al. (1991); } \\
\text { Michalewicz (1996). }\end{array}$ \\
\hline $\begin{array}{l}\text { Organiza- } \\
\text { tion and } \\
\text { manage- } \\
\text { ment }\end{array}$ & $\begin{array}{l}\text { - Work scheduling; } \\
\text { - Telecommunication networks design; } \\
\text { - Computer network optimisation; } \\
\text { - School plan arrangement; } \\
\text { - Water supply system planning. }\end{array}$ & $\begin{array}{l}\text { Bruderer (1992); } \\
\text { Biethahn \& Nissen (1994). }\end{array}$ \\
\hline Marketing & $\begin{array}{l}\text { - Distribution of products } \\
\text { - Learning models of consumer choice } \\
\text { - Optimization of product-market structures } \\
\text { - Analysis of product parity, market parity } \\
\text { and competitive advantages }\end{array}$ & $\begin{array}{l}\text { Hurley, Moutinho, \& Stephens } \\
\text { (1995); } \\
\text { Hughes (1990). }\end{array}$ \\
\hline Sales & $\begin{array}{l}\text { - Inventory simulation; } \\
\text { - Warehouse transport problems; } \\
\text { - First print estimation; } \\
\text { - Points of sale distribution; } \\
\text { - Self-learning consumer model. }\end{array}$ & Biethahn and Nissen (1994). \\
\hline $\begin{array}{l}\text { Manufac- } \\
\text { turing and } \\
\text { production }\end{array}$ & $\begin{array}{l}\text { - Production planning } \\
\text { - Intelligent manufacturing } \\
\text { - Packing problems } \\
\text { - Job shop scheduling } \\
\text { - Production line balancing; } \\
\text { - Lot size determination; } \\
\text { - Production sequencing; } \\
\text { - Storage; } \\
\text { - Load management; } \\
\text { - Optimisation of nuclear reactor operations } \\
\text { - Flight simulators programming }\end{array}$ & $\begin{array}{l}\text { Vancza and Markus (1991); } \\
\text { Stevens (1993); } \\
\text { Venugopal and Narendran (1992); } \\
\text { Ward et al. (1990); } \\
\text { Ward et al. (1992); } \\
\text { Kulkarni and Parasei (1992); } \\
\text { Dowsland and Dowsland (1992); } \\
\text { Biegel and Davern (1990). }\end{array}$ \\
\hline \multirow[t]{2}{*}{ Others } & - Facility layout and location planning & $\begin{array}{l}\text { Khuri and Batarekh (1990); } \\
\text { Tam (1992); } \\
\text { Huntley and Brown (1991). }\end{array}$ \\
\hline & - Document clustering & Gordon (1991). \\
\hline
\end{tabular}

Source: own elaboration based on Biethahn and Nissen (1994, p. 184), Hurley, Moutinho, and Stephens (1995, p. 42).

The prospects for applying EAs in management are highly satisfying. Both theorists and practitioners of EAs indicate a promising future of hybrid systems that achieve a synergistic effect by combining at least two EAs. For example, for the purposes of applying 
EAs in economics, Biethahn and Nissen (1994, p. 189) indicate six variants of their combination with simulation methods, namely:

- decision variables regulation,

- developing model structures,

- two-step optimisation using evolutionary meta-algorithms,

- meta-model simulation,

- optimisation with an adaptive agent,

- evolutionary modelling.

\section{CONCLUSIONS}

We may say with certainty that the future of Big Data and the use of artificial intelligence in industry and business begins right now (Batistic \& van der Laken, 2019; Stasik \& Wilczynska, 2018). Thanks to their numerous advantages, EAs are used in many research fields; e.g. logistics, transport, finance, insurance, scheduling, sell, marketing, local and global economy. Although the EAs are already often used in economics, we may say that they are only at an early stage of development. The current state of EAs application for the needs of the economy confirms that there has appeared no implementation breakthrough yet. The growing interest in EAs in connection with the dynamic development of information technologies can lead to the use of evolutionary algorithms in hybrid systems, which in turn will contribute to significant progress in optimisation theory.

Like any scientific article, this article is not free from research limitations. It is a report from the initial stage of research, and therefore is only exploratory. We do not overview all journals and matters related to the application of algorithms in economics, finance, and management. Therefore, the next research stage should consider a much broader spectrum in the subject approach. The overview in this article answered three exploratory questions at a general level. Thus, the next research stage should account for the specific results in the literature.

The literature query and the process of logical reasoning based on the collected material allows us to outline several directions of further research. Firstly, future studies should conduct a detailed bibliometric analysis with a map of connections that will allow a classification of research areas within the application of evolutionary algorithms in economics, finance, and management. Secondly, scholars should review the application of evolutionary algorithms in two currently developing research areas: strategic entrepreneurship and international business.

\section{REFERENCES}

Arabas, J. (2004). Wykłady z algorytmów ewolucyjnych. Warszawa: Wydawnictwo NaukowoTechniczne WNT.

Arabas, J. (2011). Evolutionary Computation for Global Optimization - Current Trends. Journal of Telecommunication and Information Technology, 4, 5-10.

Babbie, E. (2012). The Practice of Social Research. 13th ed., Belmont, CA: Wadsworth Cengage Learning. 
Batistic, S., \& van der Laken, P. (2019). History, Evolution and Future of Big Data and Analytics: A Bibliometric Analysis of Its Relationship to Performance in Organizations. British Journal of Management, 30, 229-25. https://doi.org/10.1111/1467-8551.12340

Benazzouz, N.M. (2019). Innovator's Dilemma: Review of the Main Responses to Disruptive Innovation. Journal of Intercultural Management, 11(1), 105-124, https://10.2478/joim-2019-0005

Biethahn, J., \& Nissen, V. (1994). Combinations of Simulation and Evolutionary Algorithms in Management Science and Economics. Annals of Operations Research, 52(4), 183-208.

Brereton, P., Kitchenham, B.A, Budgen, D., Turner, M., \& Khalil, M. (2007). Lessons from applying the systematic literature review process within the software engineering domain. Journal of Systems and Software, 80(4), 571-583.

Coello, C.A.C. (1999). A comprehensive survey of evolutionary-based multiobjective optimization techniques. Knowledge and Information Systems. An International Journal, 1(3), 269-308.

Collis, J., \& Hussey, R. (2009). Business Research: A Practical Guide for Undergraduate \& Postgraduate Students. 3rd ed., London: Palgrave Macmillan.

Deb, K. (2001). Multi-objective optimization using evolutionary algorithms. Chichester: Wiley.

Deb, K., Pratap, A., Agarwal, S., \& Meyarivan, T. (2002). A fast and elitist multiobjective genetic algorithm: NSGA-II. IEEE Transactions on Evolutionary Computation, 6(2), 182-197. https://doi.org/10.1109/4235.996017

Fisher, C., Buglear, J. (2010). Researching and Writing a Dissertation. 3rd edition. Harlow: Prentice Hall.

Goldberg, D.E. (1989). Genetic Algorithms in Search, Optimization and Machine Learning. Boston, MA: Addison-Wesley Longman Publishing.

Holland, J.H. (975). Adaptation in Natural and Artificial Systems. Ann Arbor: MIT Press.

Hurley, S., Moutinho, L., \& Stephens, N. (1995). Solving marketing optimization problems using genetic algorithms. European Journal of Marketing, 29(4), 39-56. https://doi.org/10.1108/03090569510086648

Ilyash, O., Dzhadan, I., \& Ostasz, G. (2018). The influence of the industry's innovation activities indices on the industrial products' revenue of Ukraine. Economics and Sociology, 11(4), 317-331. https://doi.org/10.14254/2071-789X.2018/11-4/21

Jones, D.F., Mirrazavi, S.K., \& Tamiz, M. (2002). Multi-objective Meta-heuristics: An Overview of the Current State-of-the-art. European Journal of Operation Research, 7(2), 1-9.

Khan, F., Xuehe, Z., Atlas, F., Khan, K., Pitafi, A., Saleem, M., \& Khan, S. (2017). Impact of absorptive capacity and dominant logic on ERP assimilation in Chinese firms. International Entrepreneurship Review, 3(2), 81-99. https://doi.org/10.15678/PM.2017.0302.06

Köppelová, J., \& Jindrová, A. (2017). Comparative study of short-term time series models: Use of mobile telecommunication services in $\mathrm{CR}$ regions. Agris on-Line Papers in Economics and Informatics, 9(1), 77-89. https://doi.org/10.7160/aol.2017.090107

Köppelová, J., \& Jindrová, A. (2019). Application of exponential smoothing models and arima models in time series analysis from telco area. Agris on-Line Papers in Economics and Informatics, 11(3), 73-84. https://doi.org/10.7160/aol.2019.110307

Kožíšek, F., \& Vrana, I. (2017). Business process modelling languages. Agris on-Line Papers in Economics and Informatics, 9(3), 39-49. https://doi.org/10.7160/aol.2017.090304

Layer, E., \& Tomczyk, K. (2010) Measurements, Modelling and Simulation of Dynamic Systems. Berlin Heidelberg, New York: Springer Verlag. 
Lichy, K., Mazur, M., Stolarek, J., \& Lipiński, P. (2018). The Use of Heuristic Algorithms: A Case Study of a Card Game. Journal of Applied Computer Science, 26(2), 107-116. https://doi.org/10.34658/jacs.2018.26.2.107-116

Michalewicz, Z. (1996). Genetic Algorithms + Data Structures = Evolution Programs. Berlin: Springer Verlag.

Michalewicz, Z., Fogel D.B. (2004). How to Solve It: Modern Heuristics. Berlin: Springer Verlag.

Mukerjee, A., Biswas, R, Deb, K., \& Mathur, A.P. (2002). Multi-objective Evolutionary Algorithms for the Risk-return Trade-off in Bank Loan Management. International Transactions in Operational Research, 9(5), 583-593. https://doi.org/10.1111/1475-3995.00375

Nowiński, W., \& Kozma, M. (2017). How Can Blockchain Technology Disrupt the Existing Business Models?. Entrepreneurial Business and Economics Review, 5(3), 173-188. https://doi.org/10.15678/EBER.2017.050309

Rogalska, E. (2018). Multiple-criteria analysis of regional entrepreneurship conditions in Poland. Equilibrium. Quarterly Journal of Economics and Economic Policy, 13(4), 707-723. https://doi.org/10.24136/eq.2018.034.

Prokop, J., \& Karbowski, A. (2018). R\&D spillovers and cartelization of industries with differentiated products. Journal of International Studies, 11(3), 44-56. https://doi.org/10.14254/20718330.2018/11-3/4

Sieja, M. (2010). Procedure of discrete determination of signal maximising the integral-square criterion. Technical Transactions - Electrical Engineering, 107(17), 79-86 (1-E).

Sieja, M., \& Wach, K. (2008). Implementacja algorytmów ewolucyjnych w gospodarce opartej na wiedzy. Przedsiębiorczość - Edukacja, 4, 82-89.

Shvedovsky, V., Standrik, A., \& Bilan, Y. (2016), Economic and Social Institutions: Modelling the Evolution Paths for the Archaic Society. Economics and Sociology, 9(2), 137-147. https://doi.org/10.14254/2071-789X.2016/9-2/9

Stasik, A., \& Wilczynska, E. (2018). How do we study crowdfunding? An overview of methods and introduction to new research agenda. Central European Management Journal, 26(1), 49-78.

Tomczyk, K. (2006). Application of genetic algorithm to measurement system calibration intended for dynamic measurement. Metrology and Measurement Systems, 13(1), 93-103.

Wach, K. (2015). Modern Policy for the Entrepreneurial Economy: Theoretical Considerations (chapter 1). In: A.S. Gubik \& K. Wach (Eds.), Institutional Aspects of Entrepreneurship. Miskolc (Hungary): University of Miskolc, pp. 9-18.

Wiśniewska, S., Lula, P., Oczkowska, R., \& Wójcik, K. (2019). An attempt to estimate the competency gap in the IT sector. International Entrepreneurship Review, 5(3), 95-112. http://dx.doi.org/10.15678/IER.2019.0503.07

Wyciślak, S. (2017). Implications of digitalization for value chains. International Entrepreneurship / Przedsiębiorczość Międzynarodowa, 3(2), 37-48.

Zajkowski, R., \& Domańska, A. (2019). Differences in perception of regional pro-entrepreneurial policy: does obtaining support change a prospect?. Oeconomia Copernicana, 10(2), 359-384. https://doi.org/10.24136/oc.2019.018.

Zygmunt, J. (2018). Entrepreneurial activity drivers in the transition economies. Evidence from the Visegrad countries. Equilibrium. Quarterly Journal of Economics and Economic Policy, 13(1), 89103. https://doi.org/10.24136/eq.2018.005 


\section{Authors}

The contribution share of authors is equal and amounted to $50 \%$ each of them.

\section{Marek Sieja}

Assistant professor at Cracow University of Technology, the Department of Automatics and Information Technologies at the Faculty of Electrical and Computer Engineering. He received PhD in electrotechnics in 2016. His research interests include genetic algorithms and electrical metrology. Correspondence to: Dr inż. Marek Sieja, Cracow University of Economics, Faculty of Electrical and Computer Engineering, ul. Warszawska 24, 31-155 Kraków, Poland, e-mail: msieja@pk.edu.pl ORCID (1) http://orcid.org/0000-0001-8229-0598

\section{Krzysztof Wach}

Associate Professor (Prof. SAN and Prof. UEK) of the University of Social Sciences in Łódź and Cracow University of Economics (Poland). Habilitated Doctor of Economics (DEcon, 2013), PhD in Management (2006), specialist in international entrepreneurship, author of several books and over 200 scientific articles, editor-in-chief of the scientific quarterly Entrepreneurial Business and Economics Review (ESCI WoS, Scopus), member of editorial boards of several scientific journals, including the European Journal of International Management (SSCI WoS); in 2012-2018 an OECD and European Commission national expert for entrepreneurship; participant of various international education and research projects; e.g. Jean Monnet, Atlantis, International Visegrad Fund IVF, Central European Initiative CEI; visiting professor at various foreign universities, including the USA, the UK, Spain, Croatia, China, Taiwan, Austria, Slovakia, and Ukraine.

Correspondence to: Prof. Krzysztof Wach, PhD, University of Social Sciences in Łódź, Department of Entrepreneurship and Family Firms, ul. Sienkiewicza 9, 90-113 Łódź, Poland, e-mail: kwach@san.edu.pl

ORCID (1) http://orcid.org/0000-0001-7542-2863

\section{Copyright and License}

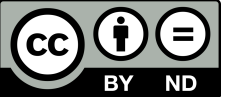

This article is published under the terms of the Creative Commons Attribution - NoDerivs (CC BY-ND 4.0) License http://creativecommons.org/licenses/by-nd/4.0/

Published by the Centre for Strategic and International Entrepreneurship - Krakow, Poland 